\title{
Usefulness of Mobile Assisted Language Learning Application
}

\author{
Kashif Ishaq, Nor Azan Mat Zin, Fadhilah Rosdi, Adnan Abid, Qasim Ali
}

\begin{abstract}
The focus of this article to examining the District Monitoring Officer (DMO) and Assistant Commissioner (AC)'s perception for Literacy \& Numeracy Drive (LND) a mobile-based application that is used in primary schools of public sector in Punjab province, Pakistan to teach student of Grade 03 on a tablet for learning languages and Mathematics. This study aims to gauge the efficacy of LND for its usefulness, usability, accessibility, content, and assessments. Semi-Structured interviews conducted for the purpose of study from the DMO and AC of District Sheikhupura, to measure the effectiveness of LND and evaluate the effectiveness. The result reveals, in its current form, the LND application is not effective and needs improvement in usability, design, content, accessibility, infrastructure, and assessment. Furthermore, DMO and AC recommended that game-based learning consists of an interactive interface, phonics, animations to be developed and adopted. As a more interactive and attractive presentation of the content and variations in the assessment may increase students' involvement and will make this application more effective and will produce good results.
\end{abstract}

Keywords: Assessment, Usability, Content, Design, Mobile Application, Language Learning

\section{INTRODUCTION}

English is not a subject which can be taught; it is a subject which must be learned (Michel West). English is a universal language and is spoken worldwide. It's an effective communication process and it is learned mainly by native speakers and taught as a second language by a number of nations (Mudra, 2018). English is the medium of education at all levels of schooling (Muhammad, Ya, Aliyu, \& Hassan, 2018). The importance of English in teaching has been recognized in most states and the use of modern instruments to facilitate the study of English is important when it is not the primary language (Yadegaridehkordi, \& Alaa, 2017). To survive in the world it is essential to learn English as a second language. However, English encourages the candidates to higher education and lets them achieve better employment opportunities (Eriksson, 2019).

Revised Manuscript Received on February 05, 2020.

* Correspondence Author

Kashif Ishaq*, Universiti Kebangsaan Malaysia, Bangi, Malaysia. P97710@siswa.ukm.edu.my

Nor Azan Mat Zin, Universiti Kebangsaan Malaysia, Bangi, Malaysia. azan@ukm.edu.my

Fadhilah Rosdi, University of Management and Technology, Lahore, Pakistan. fadhilah.rosdi@ukm.edu.my

Adnan Abid, University of Management and Technology, Lahore, Pakistan.adnan.abid@umt.edu.pk

Qasim Ali, University of Management and Technology, Lahore, Pakistan.qasimali15001@gmail.com

(C) The Authors. Published by Blue Eyes Intelligence Engineering and Sciences Publication (BEIESP). This is an open access article under the CC BY-NC-ND license (http://creativecommons.org/licenses/by-nc-nd/4.0/)

\section{LITERACY AND NUMERACY DRIVE (LND):}

Out-of-date large scale assessment processes were expensive, multi-faced, and irregular for primary students conducted by Punjab Examination Commission. In 2015, the Ministry of School Education and the Informatics Board of Punjab launched a mobile application named the "Literacy and Numeracy Drive", (Figures: 1) which was classified as a low-cost system to teach English, Urdu and Mathematics in all Punjab public sector colleges, Pakistan and used by monitoring and evaluation assistant (MEA) on regular oncea-month visits to each public school. The application is connected to a large question bank and the student's learning results for each question ("Literacy \& Numeracy", 2019).

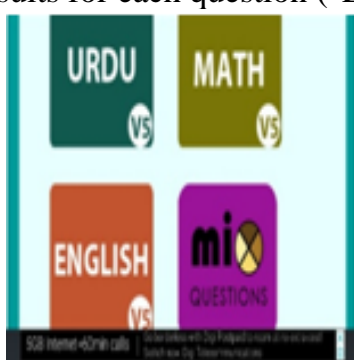

(a): User Interface of LND

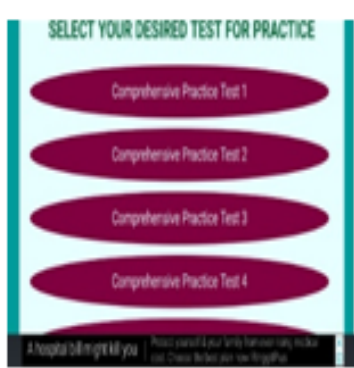

(c): Engish Comprehesion

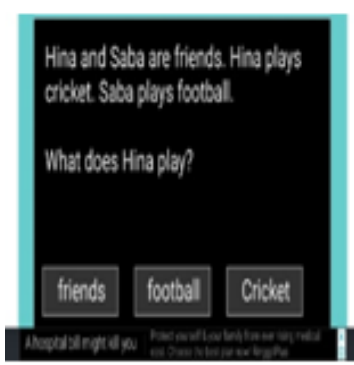

(e): English Test II

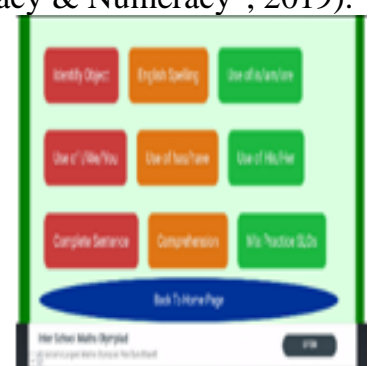

(0): Main dasthoard of Engibh

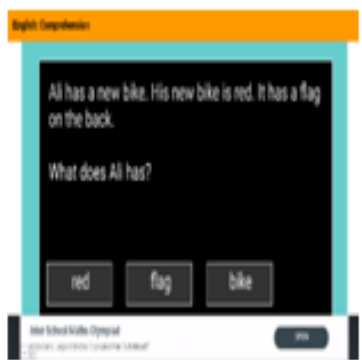

(d): Erggish Test I

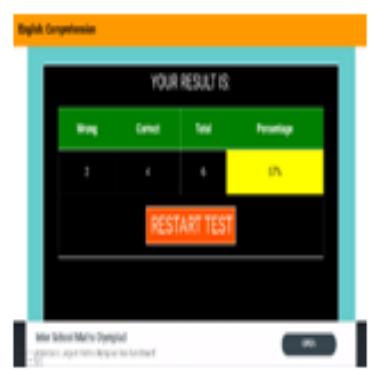

(f): LND Test Assessment
Figure 1: LND Screens 
School Education Department, Punjab used LND software to review grade three student accomplishments on a monthly basis to achieve better learning results as previously mentioned. Students are trained in three basic subjects on a mobile application according to the Prescribed Students Learning outcomes (SLOs), which are Mathematics, English and Urdu ("Literacy \& Numeracy" 2019). Nevertheless, the main research emphasis is only on the topic of the language, because the teachers ' English teaching difficulty lies in their non-native language (Haidar, 2019; Shamim, 2019). Rural schools in Pakistan have no exceptional access to technology that can help teaching and learning of English.

\section{THE ASSESSMENT PROCESS OF LND:}

Monitoring and Evaluation Assistant (MEAs) normally select 7-10 Grade 3 students at random for assessment and evaluation and assign them the questions to solve on his own tablet. MEA then asks random questions to selected students, as per report question-based to complete the evaluation process for the specific class, theme and the main student learning outcome (SLO) ("Literacy \& Numeracy" 2019).

There are more than 52000 public sector schools throughout the Province of Punjab in which this assessment is carried out on a monthly basis, with each pupil given a minimum of seven questions. A selected student takes less than five minutes to answer the questions. A total of 329,000 students are tested each month. Until now the MEAs have been assessing 6.7 million students and students' assessment information is being submitted to academic administrators via SMS and the electronic dashboard on the official website for the study (PMIU, 2018),. The monthly assessment outcome for each school in each section of all districts of the Province of Punjab is made available free of charge.

\section{LITERATURE REVIEW AND THEORETICAL FRAMEWORK}

English is becoming increasingly important in many areas of human life, including literacy, financial affairs, regulatory problems, anticipation, entrepreneurship, and commerce (Fareed, 2018). This increased the need for English to the level that residents of modern societies are sufficiently skilled for success in their academic and professional life (Shamim 2019). Emery, (2012) carried out a study in 89 countries worldwide to determine the process for preparing and educating English teachers, the results show that educators are not specifically trained in English and that this is not an issue for a country or region, but it is the problem across the globe. Thus the challenge is to train teachers for teaching English

\section{Technology Acceptance Model}

Technology Acceptance Model (TAM) has used in research in the past 20 years (Al-emran, Mezhuyev, \& Kamaludin, 2018). The model was structured to illustrate a wide variety of machine information predictors through various researchers (Venkatesh et al., 2003), based on the principle of rational behavior (Fishbein and Ajzen's, 1975). TAM is a traditional component of five: perceived utility, userfriendliness, mutual purpose and discreet usage (Venkatesh, 2000). Numerous researchers have identified TAM (Park, 2009) and according to (Venkatesh, 2008) the devices may be used by about 40 percent of the total. However, the model played an significant role in predicting its use of a number of aspects (King, 2006).

TAM (Davis et al. 1989) have been revised to TAM 2 (Venkatesh, Thong \& Xu 2012) and adapted to a Unification Theory of Acceptance and use of Technology (UTAUT) (Petter, 2008). There have also been comprehensive TAM variations to check the acceptance of customers with a number of learning skills in a wide range of settings (Abdullah \& Ward, 2016).

\section{Perceived Ease of Use:}

An essential determinant of the objective is the ease of use of computer programs within the TAM. A discreet man defines a simple use as simple in the implementation of a process (Venkatesh \& Davis, 2000) and directly beneficial. Nevertheless, conventional TAM (Gefen et al., 2003) includes the use of a technique by conducts against the use of such tests (Park, 2009). In addition, a number of the studies have not established direct ties between ease of use and user motivation, as claimed to be involved in the work of technology under these parameters (Moon and Kim 2001). A study of Boyle et al. (2016) indicates that it is important for programs to create sufficient mysteries in those areas so that learning tests and game software can be made easy to use (Schell, 2019). Results of the research by Hamari, (2017) conclude that presumed user-friendliness does not give digital game students satisfaction. However, Supriana et al. (2017) found that 'easy to use' is one of the player expectations.

\section{Perceived Usefulness:}

The main indicator of the decision to use TAM technologies is the Perceived Usefulness, "that an individual feels that using a particular system can increase their work performance" (Davis, 1989, p. 320; Venkatesh and David, 2000). The use of the term performance can however imply a focus on the outcome or effect over the use phase in this context. This may be sufficient in many cases, however, if not more critical than the result, the education process itself can be equally relevant.

\section{Technology in Education:}

Technology has revolutionized the field of learning and its importance is taken into account in classrooms. Technology includes four overlaps: a training program, a teaching structure, a means for delivering instruction, and an infrastructure for upgrading the whole learning process (Ţălu, 2019). Recently, students have been able to connect on the Internet to become actively involved in interactive games by extending the growth of new modernized and netbased technologies (Ashraf et al. 2014).

Research on instructional technology use in Pakistan is still lacking. Most studies examined student and educator uses of social networking websites in teaching and teacher environments, as well as the general use of the web by higher school students (Lee, 2019). The use of software in the life of students has so grown, that the teaching of language comprehension by graphic and video imagery is important for students (Cakir, 2006). 
Teachers consider the assumption and usage of Information \& Communication Technology (ICT) in teaching since they are the key to making learning take place (Hussain et al., 2010).

\section{Teaching English as a Second Language (TESL) in primary school:}

The second language is English in Pakistan where English and Urdu languages are used as educational and official languages. English grammar rules are very hard to understand, especially the students in rural schools, who have to learn it as a second language. English teaching is also an issue to the education of students (Naveed, 2018). The progress of students in English language education is influenced by many variables, their social and cultural context, educator employment, curriculum, school resources and facilities. In order to improve English language learning, all the related factors must be addressed (Coleman \& Capstick, 2012).

Globally, educators are gradually utilizing electronic tools for language learning as teachers and students are only interacting in the classroom in modern schools, whereas the learning environment has shifted with iPads, iPhones and other Mobile apps (Wang et al., 2017). Virtual software (Mchucha et al. 2017) allows students to interact in an environment in order to improve motivation to learn a topic. Research on the use of education services in the global digital language industry. Heil et al., (2016), reported that its use exceeded $\$ 1.8$ billion in 2013 and that sales will hit more than \$3.1 billion. Using Applications such as Duo Lingo has become commonly used in language learning (Duolingo AI Research, 2019) with over 70 million subscriptions.

\section{Mobile-Assisted Language Learning (MALL):}

UNESCO (2013), listed the use of active electronic training and education platforms as tablets, mobile devices, ereaders, handheld gaming consoles, digital audio players, notebooks, netbooks, and consoles. Mobile Language Learning Applications (MALL) are well-defined as the use of mobile phones for learning linguistic (Ali, Malik, \& Rehman, 2016). Mobile telephone helps students to learn their own language skills and write effortlessly and Mobile devices, are commonly used for academic and growth purposes in developing countries (Zhang, 2016) similar to western countries. The transition in pedagogical methods to mobile technology has been successful. The introduction of mobile devices into the program allows students free of time and space constraints to train freely by using new software such as simulations, research plays, digital testing and language applications (Ismail, Harous, and Belkhouche, 2016). The smartphone is used for various types of activities such as watching movies, social networking and games, money transfers, control to data, and Internet access (Ali et al., 2016). By 2012, 1.2 million individuals will use mobile applications globally, and 4.4 million by 2017 (Abdulvahap et al. 2018). Mobile learning is a utility that automatically provides the student with universal information and makes content that helps to achieve available knowledge (Hidayat \& Utomo 2014).

In contrast to traditional computer equipment, students will take advantage of segmented time to learn without restriction of time and place with the help of availability, versatility and user friendliness in mobile technology
(Zhang 2016). The benefits of MALL are easily one of low cost, durability, small size, user-friendliness and more advanced (Huang, \& Lin, 2011). Mobile phones are also able through pre-custom programming to provide language learners with understandable data, provide access to opportunities for exchange of meaning via the link with technology or teachers and create a student-oriented learning environment (Zhang, 2016). Past research indicates that MALL has an effect on language, self-governance, and perception of literacy (Hazaea and Alzubi, 2018). Furthermore, the use of the Internet to access new information on request indicates the consumer is needed, while McQuiggan et al. (2015) suggest the potential to do so. Informal training, including social and technological factors, can lead to an established personal education and environmental opportunity, with the student in mind.

On the other hand, online learning may not be ready to test emerging new technologies (Hsu et al., 2013). There are also concerns. Mobile applications are distributed in App Store (iOS), Android (Play Store) and other repositories. Requirements include the application capabilities, offline functions, discoverability, speed, delivery, management and network independence, software limits, authorization processes, charges, development costs, and user interfaces also include strengths and weaknesses. The design of mlearning software is another activity requiring professional skills and contours. Either the way the world is converted into software or the improvement in the frameworks (and not invention) in the use of m-learning tools regulates the success of students (Abdulvahap et al. 2018).

Unfortunately, in general, the electronic literacy model is an obstacle for both teachers and learners (Brown, \& Mbati, 2015), as there are other issues of technological discrimination and conduct, for instance, adjustment, usability and subscription charges (Miangah, 2012).

\section{Challenges of English Language Learning in Pakistan:}

In Pakistan, the education instructions can be classified according to the socio-economic status. The educational system includes public, private and religious institutions, where Urdu is widely used as a learning medium, whereas English language is used in private, and more elite schools (Karamouzianet al., n.d). Multilingual classes for educators as well as learners are the primary challenge of English not only in Quetta, Pakistan but also in other parts of the sphere. Various local dialects and languages are spoken by students in the classroom, thus teachers and students have many challenges with English teachers facing a greater challenge of dealing with different language speakers in classrooms (Rasheed et al., 2017).

Various challenges faced by English instructors and pupils include the ignorance of the professors, educational policy and the examination system and long curricula (Khan \& Khan, 2016). The need for language skill is not recognized at any point in Pakistan's learning in the form of the English curricula, as students at the university level face problems with English subjects despite the fact that they are compulsory subject matter at the school level. In terms of public education, the Standard English instruction approach is used, and no suggested framework is used for evaluating or improving the language skills in government schools (Naheed, 2015). 
Language is known as an entity that primarily facilitates communication with humans. The English Syllabus for Pakistan (ESP) is designed and implemented to provide English to teachers and to use communicative/interactive methods (Naheed, 2015). English is especially complex in Pakistan because the state's economy, military and higher education are and always ruled the country before independence by the language of power and the language of the ruling class (Coleman, 2012).

Many instructors are aware with writing skills such as thinking, ability definition and pre-writing conversations about the subject, but many factors, including the lack of time and poor educational backgrounds, restricted instruction and lack of skill in reading and teaching, are considered difficulties in learning the language.

In the public and in low-cost private schools in particular, the quality of learning is very poor throughout the country. Students have shown sustained low levels of competence of technology, mathematics and languages over the years in appraisal tests at national level. Higher learning outcomes are directly related to the low quality of education, as their low levels of familiarity and weak pedagogy are the main causes of teachers in Pakistan, for low quality of education. According to the (National Education Policy Framework 2018) Pakistani schools are faced shortage of qualified educators, particularly for English, Science and Mathematics. While many public-sector schools have English as their language learning tool, children are still incompetent in basic language skills because of the low ability of second language educators to teach English (' National Education Policy Framework, 2018). To overcome the issue of leaning languages through technology, Government of Punjab introduced LND in 2015 at primary level for teaching and learning at Grade three only. This application is adopted in 36 Districts of Punjab province in public sectors schools.

LND has been introduced since 2015 to date but the usefulness of LND has not been studied. Therefore, this is a first study on LND, a mobile-based application presently implemented by the school education department for the instruction of English, Urdu and Mathematics. Our focus is on the English module of LND.

\section{Research Objective:}

- To identify the factors that affect usage of MALL based tool (LND) for TESL in Punjab, Pakistan.

\section{Research Question:}

- What is the District Monitoring Officer (DMO)'s perceptions of LND on its usefulness, user experience, content, usability, accessibility, and assessments?

- What is the Assistant Commissioner (AC)'s perceptions of LND for its usefulness, user experience, content, usability, accessibility, and assessments?

\section{METHODOLOGY}

An interview was conducted separately in the offices of DMO and AC, District Sheikhupura, Punjab, to elicit their opinion about the usability, effectiveness, usefulness, content of LND mobile app. These two officers are the toplevel authorities monitoring the activities related to LND in public sector schools.

\section{Setting and Sample:}

The study was conducted in Pakistan's public sector primary schools composed of four provinces, Punjab, Sindh, Khyber Pakhtunkhwa, and Balochistan. Punjab Province is Pakistan's most populous area, further split into 36 districts, chosen for this analysis. It has 52,394 schools 12,268,981 pupils (both men and women) and 403,172 educators (both men and women). District Sheikhupura that was selected for the study has five different regions Ferozwala, Muridke, Safdarabad, Sharaqpur and Sheikhupura.

\section{Participants of the study:}

The District Monitoring Officer (DMO) and Assistant Commissioner (AC), District Sheikhupura, Punjab, Pakistan were the participants who are serving administratively for a long time in the said district. The main responsibility of both officials is to monitor the educational activities in all public sector schools of their region especially activities conducted for LND. Also to monitor the MEA, who conduct the exams of LND once in a month in every public school of a specific region.

\section{Instrument and Data Collection:}

This instrument is a semi-structured interview, scheduled at 10:45 am to 11:45am. The researcher conducted an interview himself with DMO and AC separately in their offices that lasts for one hour each, in autumn 2019. The interview was in two sessions, in the first session the demographic information: age, education, job experience was asked and in the second session, questions related to LND: usability, usefulness, content, and its effectiveness was asked. Furthermore, the process of teaching and assessment using LND was also inquired in local settings. Lastly, the missing features in LND were inquired and recommendations were also inquired to make it more interactive, interesting, and useful for students.

\section{Data Analysis}

An inductive methodological approach is used to analyses the interview data. Every interview was transcribed and interpretation of each interview was created. Then data was analyzed by defining, coding and classifying the answers obtained from the interview. The goal was to distinguish qualitative data for content analysis by choosing quotes or statements that go hand in hand, and which are indicators of the same basic idea, problem or definition, to promote the search in a specific setting. Followed by a case-by-case analysis, the content analysis consisted of similar terms from both interviews and wider categories. During the analytics cycle, data was labeled, categorized and then analysis was performed for the data.

The interview was conducted in Urdu language which is the nationwide language of Pakistan and it was the challenge of translating the quotations presented in this paper. In order to be presented here the details (transcripts in Urdu) translated into English. One of the main tasks was the translation and the analogies and the accurate significance in the official accounts interviewed at the same time. 


\section{RESULTS AND DISCUSSIONS}

The findings of the studies are presented as follows in the Table 1:

Table 1: Findings of the Study

\begin{tabular}{|c|c|c|c|}
\hline Sr. & Heading & Response (in English) & Response (in Urdu) \\
\hline 1 & $\begin{array}{l}\text { Multi Language issue } \\
\text { (Punjab, Urdu, and } \\
\text { English) }\end{array}$ & $\begin{array}{l}\text { The } 1^{\text {st }} \text { reason for this problem is } 03 \\
\text { languages that student has to learn in their } \\
\text { society because they have to speak Punjabi } \\
\text { at their homes with parents, then Urdu in } \\
\text { school as it is our national language and } \\
\text { lastly English language to learn by students } \\
\text { in their schools. This situation creates a lot } \\
\text { of pressure and burden on the student that } \\
\text { makes them not clear with their } \\
\text { studies/future. }\end{array}$ & 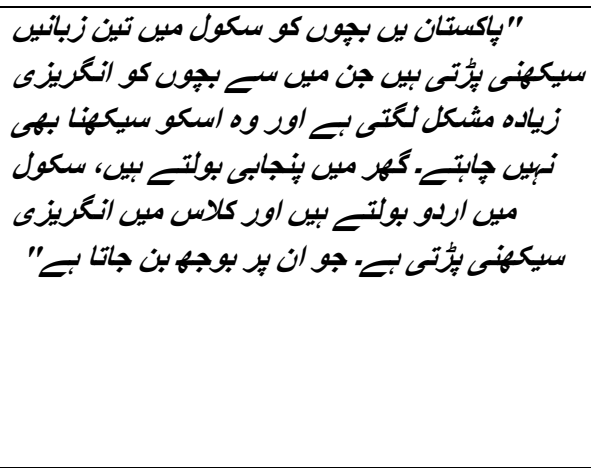 \\
\hline 2 & $\begin{array}{l}\text { Content (Different } \\
\text { content) }\end{array}$ & $\begin{array}{l}\text { Content is decided by Punjab Curriculum } \\
\text { and Textbook Board, Government of } \\
\text { Punjab, Pakistan ("Punjab Curriculum and } \\
\text { Textbook Board", 1970), therefore, the } \\
\text { content of LND application is different } \\
\text { from the content of textbook, so the } \\
\text { students have to cover both syllabi in class } \\
\text { during the defined time period. }\end{array}$ & 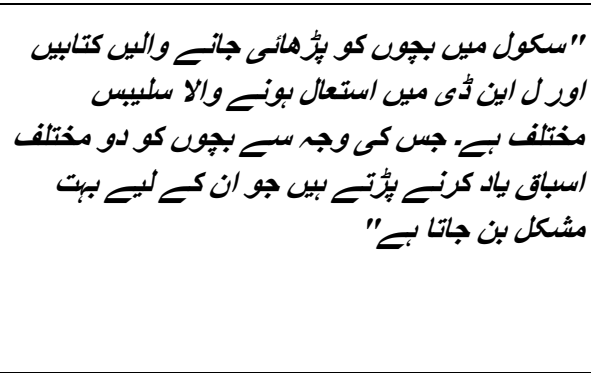 \\
\hline 3 & $\begin{array}{l}\text { Design \& Usability } \\
\text { (Colorful Pictures, } \\
\text { Icons, and Screens) }\end{array}$ & $\begin{array}{l}\text { Non-professional design of the LND } \\
\text { application, no interactivity for students to } \\
\text { use it with fun and learn effectively. Most } \\
\text { teachers are old generation who are not } \\
\text { familiar with the use of technology and } \\
\text { cannot operate the mobile tool well to teach } \\
\text { the student in the class. }\end{array}$ & 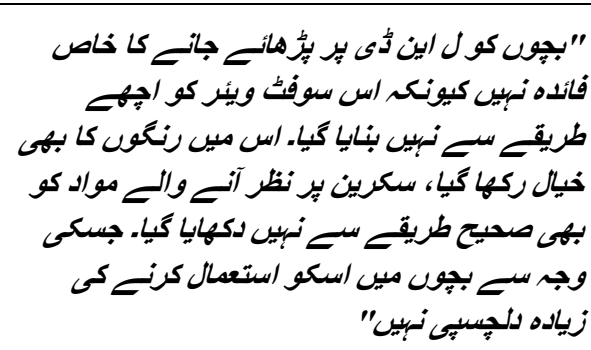 \\
\hline 4 & Assessment (Not fair) & $\begin{array}{l}\text { Assessment is not fair. There is always } \\
\text { pressure on students to be evaluated by } 3^{\text {rd }} \\
\text { party persons once a month the LND do not } \\
\text { have any function to record the assessment } \\
\text { results, so that the teacher can focus on } \\
\text { students who have the problem in learning } \\
\text { topics. }\end{array}$ & 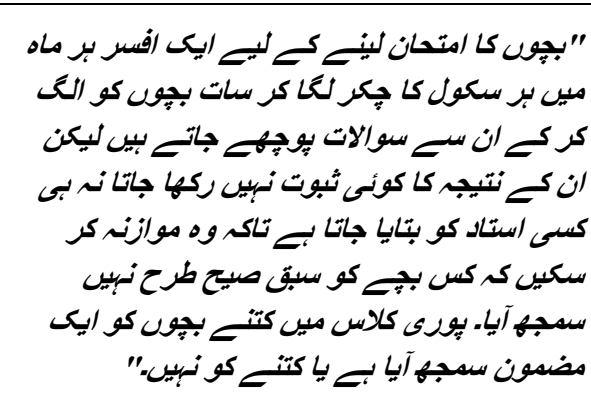 \\
\hline 5 & Application Provider & $\begin{array}{l}\text { Application provider do not allow any } \\
\text { stakeholder to give feedback for LND } \\
\text { design, User Experience, Content or } \\
\text { Assessment. In fact, the new technology } \\
\text { was enforced without consulting their users. }\end{array}$ & 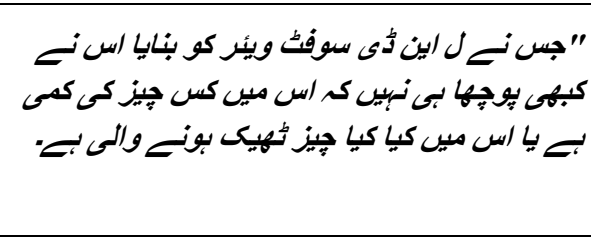 \\
\hline 6 & Overall Comments & $\begin{array}{l}\text { The method of teaching and assessment is } \\
\text { good but LND mobile application is not rich } \\
\text { enough and not effective to help students in } \\
\text { interactive way (fun based learning), } \\
\text { animations, and voice pronunciations. }\end{array}$ & 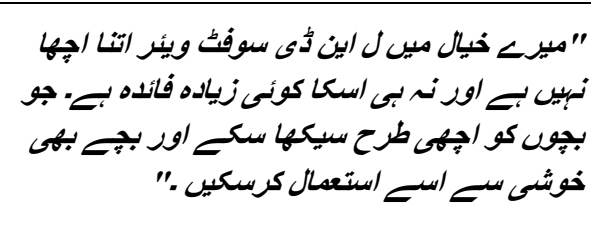 \\
\hline
\end{tabular}

Retrieval Number: B4549129219/2020@BEIESP DOI: 10.35940/ijeat.B4549.029320 Journal Website: www.ijeat.org 
The informants in this study were selected because they are actively involved in the educational activities of public sector schools in District Sheikhupura, Punjab. They expressed support for this study, and mentioned that nobody has conducted research on LND mobile application to date.

The findings in this study confirm that the LND application is not useful, effective and usable that could help students to improve their academic performance and confidence. Most importantly, voice pronunciation and video animations are missing in the LND application that could help students to learn effectively with more interest. The content used in the LND application is not suitable because content used in routine class is different than the content used in an application that creates a problem for the students to learn different content at the same time. Lastly, the assessment method is not suitable that could help teachers to identify the students who are not performing well in the class so, the teacher can put effort into them only. Even in the current form of LND, it is unable to record the results of students during class practices so, teachers or school principals can make decisions on the basis of results.

\section{RECOMMENDATIONS}

After conducting the interview from DMO and AC, to see the usefulness, usability, content and effective use of LND in schools to teach students of grade 03, several recommendations are mentioned to improve the mobilebased LND application to overcome all the issues.

1. To increase the interactivity and usability of the LND software for teachers and students, so that they can use it to teach efficiently and to teach students English with fun. It is best to learn the game foundation, which generates effective results, as students enjoy playing games and learning while playing games. During the development of this game base software, the developers must take into account its functionality, provided that the users are 03 grade. These arguments have also been emphasized by Gabriel et al., (2018). The interface layout should be appealing in a game-based study application which will have a good effect and will promote the reading of the games mentioned by (Laamarti et al., 2014), usefulness, ease of use and clear target as well as music and word pronunciation (Arnab, Petridis, Dunwell, \& De, (n.d.).

2. Teachers could save their energy and be sensitive to using the software in order to cover the course accurately and vice versa, and have the LND material the same as in the text. In a game-based learning application that should have targeted content, because it may help more people to reach success in different learning contexts than those who do not, as Lameras et al. (2017) and Giessen (2015) also mention it.

3. Avoid the evaluation by the third party which the Punjab government is currently implementing and allow the educator to use silent analysis during classroom training and assessment, submit the results to a different website to monitor and review the performance of students for additional requirements. The foundation of the game should have an equal assessment to assess the learning increase and also to monitor games as progress provides educators with immediate feedback on what they want and which material, explains and surprises in the game that could be an explanation why games should be used successfully (Zhonggen, 2019).

4. The software developer is expected, based on advice and guidelines received by LND users for development, functionality, quality, and evaluation, to seek input from LND users for changes.

\section{CONCLUSION}

Based on the results of the interview, it is verified that the $\mathrm{L}$ ND mobile application is not productive to teach grade three students as several problems have been identified: Usability, Design, Content, Accessibility, and Assessment. The officers recommended to develop a game base learning application that cover all the aspects i.e. Animations, Voice pronunciations, Videos, Sounds, Assessment records and analytics from assessments. The author is going to conduct a study to measure the usability, usefulness of LND application from teachers and students of public sector schools as well as to gather the requirements to develop a game for learning purposes according to the recommendations of DMO and AC.

\section{REFERENCES}

1. Abdulvahap, S., Lütfiye, G., Derya, U., \& Murat, A. (2018). A Review of Current Studies of Mobile Learning. Journal of Education Technology \& Online Learning, 1(1), 13-27.

2. Al-emran, M., Mezhuyev, V., \& Kamaludin, A. (2018). SC. Computers \& $\quad$ Education. https://doi.org/10.1016/j.compedu.2018.06.008

3. Ali, M. M., Malik, N. A., \& Rehman, A. (2016). MOBILE ASSISTED LANGUAGE LEARNING ( MALL ) AN EMERGING TECHNOLOGY IN ENGLISH LANGUAGE CLASS ROOMS OF. 28(2), 1629-1636.

4. Arnab, S., Petridis, P., Dunwell, I., \& De, S. (n.d.). Enhancing Learning in Distributed Virtual Worlds through Touch : A Browserbased Architecture for Haptic Interaction.

5. Boyle, E. A., Hainey, T., Connolly, T. M., Gray, G., Earp, J., Ott, M., ... Ribeiro, C. (2016). Computers \& Education An update to the systematic literature review of empirical evidence of the impacts and outcomes of computer games and serious games. 94, 178-192. https://doi.org/10.1016/j.compedu.2015.11.003

6. Brown, T. H., \& Mbati, L. S. (2015). Mobile Learning: Moving Past the Myths and Embracing the Opportunities. 16(2), 115-135.

7. Cakir, I. (2006). THE USE OF VIDEO AS AN AUDIO-VISUAL MATERIAL IN FOREIGN. Turkish Online Journal of Educational Technology-TOJET, 5(4), 67-72.

8. Coleman H.; Capstick A. (2012). Language in education in Pakistan: Recommendations for policy and practice. British Council.

9. Davis, F. D. (1989). Perceived usefulness, perceived ease of use, and user acceptance of information technology. MIS Q, 13(3).

10. Duolingo AI Research. (n.d.). Retrieved December 3, 2019, from https://ai.duolingo.com/

11. Emery, H. (2012). A global study of primary English teachers' qualifications, training and career development. British Council.

12. Eriksson, L. E. (2019). T eachers' and students ' attitudes and p erceptions toward varieties of English in Swedish upper secondary. ASLA-Symposiet i Karlstad, 2018, 207-233.

13. Fareed, M. (2018). Teaching English Language at SSC Level in Private Non-Elite Schools in Pakistan: Practices and Problems. Journal of Education and Educational Development, 5(1), 80-95.

14. Fishbein, M., \& Ajzen, I. (1975). Intention and Behavior: An introduction to theory and research.

15. Gabriel, P., Furtado, F., Hirashima, T., \& Yusuke, H. (2018). A Serious Game for Improving Inferencing in the Presence of Foreign Language Unknown Words. 9(2).

16. Gefen, David; Karahanna, Elena; Straub, D. W. (2012). Trust and TAM in Online Shopping: An Integrated Model. MIS Q, 27(1), 5190.

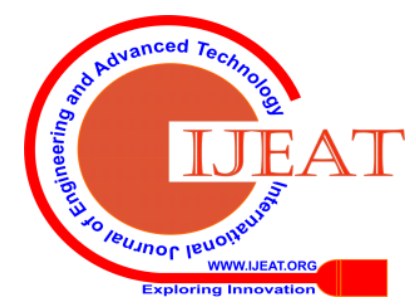


17. Giessen, H. W. (2015). Serious games effects : an overview. Procedia Social and Behavioral Sciences, 174, 2240-2244. https://doi.org/10.1016/j.sbspro.2015.01.881

18. Haidar, S., \& Fang, F. G. (2019). English language in education and globalization: a comparative analysis of the role of English in Pakistan and China. Asia Pacific Journal of Education, 00(00), 1-12. https://doi.org/10.1080/02188791.2019.1569892

19. Hamari, J., \& Keronen, L. (2017). International Journal of Information Management Why do people play games? A metaanalysis. International Journal of Information Management, 37(3), 125-141.

20. Hazaea, A. N. (2018). Impact of Mobile Assisted Language Learning on Learner Autonomy in EFL Reading Context. 4(2), 48-58. https://doi.org/10.17323/2411-7390-2018-4-2-48-58

21. Heil, C. R., Wu, J. S., \& Lee, J. J. (2016). Review paper. 24(2), 32 50.

22. Hidayat, A., \& Utomo, V. G. (2014). Open Source Based M-Learning Application for Supporting Distance Learning. 12(3), 657-664. https://doi.org/10.12928/TELKOMNIKA.v12i3.104

23. Hsu, C., Hwang, G., \& Chang, C. (2013). Computers \& Education A personalized recommendation-based mobile learning approach to improving the reading performance of EFL students. Computers \& Education, 63 ,

327-336. https://doi.org/10.1016/j.compedu.2012.12.004

24. Huang, L., \& Lin, C. (2011). EFL learners 'reading on mobile phones. 7(1), 61-78.

25. Hussain, M. A., Niwaz, A., Zaman, A., Dahar, M. A., \& Akhtar, M. S. (2010). TECHNOLOGY BASED LEARNING ENVIRONMENT AND STUDENT ACHIEVEMENT IN ENGLISH AS A FOREIGN LANGUAGE IN PAKISTAN. 2(5), 398-403.

26. Ismail, H., Harous, S., and Belkhouche, B. (2016). A Comparative Analysis of Machine Learning Classifiers for Twitter Sentiment Analysis. Research in Computing Science.

27. Karamouzian, F. M., \& Ahmed, F. (n.d.). A Post-Use Evaluation of Pakistani Secondary School English Textbooks. TESOL International Journal, 9(1), 15-37.

28. Khan, T. J., \& Khan, N. (2016). Obstacles in Learning English as a Second Language among Intermediate Students of Districts Mianwali and Bhakkar , Pakistan. Open Journal of Social Science, (February), 154-162.

29. King, W. R., \& He, J. (2006). A meta-analysis of the technology acceptance model. Information \& Management, 43, 740-755. https://doi.org/10.1016/j.im.2006.05.003

30. Laamarti, F., Eid, M., \& Saddik, A. El. (2014). An Overview of Serious Games. International Journal of Computer Games Technology.

31. Lameras, P., Arnab, S., Dunwell, I., Stewart, C., \& Clarke, S. (2016). Essential features of serious games design in higher education: Linking learning attributes to game mechanics. British Journal of Educational Technology.

32. Lee, Y. J. (2019). Australian Journal of Applied Linguistics Integrating Multimodal Technologies with VARK Strategies for Learning and Teaching EFL Presentation: An Investigation into Learners Achievements and Perceptions of the Learning Process. 2(1), 17-31.

33. Literacy and Numeracy.

(2019) https://open.punjab.gov.pk/lnd/reports/open_slo charts, Retrieved on November 24, 2019.

34. Mchucha, I. R.; Ismail, Z. I., \& Tibok, R. P. (2017). Developing a Gamification-Based Thesaurus App to Improve English Language Vocabulary: A Case study of Undergraduate Students in Malaysia. CARNIVAL ON E-LEARNING (IUCEL), 43.

35. McQuiggan, S.; McQuiggan, J.; Sabourin, J.; \& Kosturko, L. (2015). Mobile learning: A handbook for developers, educators, and learners. John Wiley \& Sons.

36. Miangah, T. M., \& Nezarat, A. (2012). Mobile-Assisted Language Learning. International Journal of Distributed and Parallel Systems, 3(1), 309-319.

37. Moon, J., \& Kim, Y. (2001). Extending the TAM for a World-WideWeb context. Information \& Management, 38(June 2000).

38. Mudra, H. (2018). Pre-Service EFL Teachers' Experiences in Teaching Practicum in Rural Schools in Indonesia Pre-Service EFL Teachers' Experiences in Teaching Practicum in Rural (Vol. 23).

39. Muhammad, H. A., Ya, S., Aliyu, U. I., \& Hassan, M. (2018). Teaching and Learning English Language in Nigerian Schools: Importance and Challenges. 3, 10-13 https://doi.org/10.11648/j.tecs.20180301.13

40. Naheed, F. (2015). Interactive Approach in English Language Learning and Its Impact on Developing Language Skills. Dialogue, $\mathrm{X}(1)$.
41. National Education Policy Framework. (2018, November). Ministry of Education and Professional Training. Pakistan.

42. Naveed, A. ., Shah, T. H., Shafiq-Ur-RS, \& Pervaiz, A. (2018) Critical Analysis of English Language Teaching Skills, A Study of Primary School Teachers of Taluka Kotdiji, District Khairpur Mir's. SciFed Journal of Telecommunication, 2(1), 1-6.

43. Nielsen Norman Group. (2019). Mobile: Native Apps, Web Apps, and Hybrid Apps. [online] Available at: https://www.nngroup.com/articles/mobile-native-apps/ [Accessed 26 Nov. 2019].

44. Park, S. Y. (2009). An analysis of the technology acceptance model in understanding university students' behavioral intention to use elearning. Educational Technology \& Society, 12(3)

45. Petter, S., Delone, W., \& Mclean, E. (2008). Measuring information systems success: models, dimensions, measures, and interrelationships. European Journal of Information Systems, 17(December 2006), 236-263. https://doi.org/10.1057/ejis.2008.15

46. PMIU. (n.d.). Retrieved November 13, 2019, from https://open.punjab.gov.pk/lnd/reports/district map

47. Punjab Curriculum and Textbook Board. (1970, November 01). Retrieved November 24, 2019, from https://pctb.punjab.gov.pk/

48. Rasheed, S., Zeeshan, M., \& Zaidi, N. A. (2017). Challenges of Teaching English Language in a Multilingual Setting: An Investigation at Government Girls Secondary Schools of Quetta , International Journal of English Linguistics, 7(4), 149-157. https://doi.org/10.5539/ijel.v7n4p149

49. Schell, J. (2019). The Art of Game Design: A book of lenses. AK Peters/CRC Press.

50. Shamim, F. (2019). The English / Urdu-Medium Divide in Pakistan: Consequences for Learner Identity and Future Life Chances. Journal of Education and Educational Developement, 6(1), 43-61.

51. Ţălu, Ş. (2019). Implications of modern digital technologies in higher education. 105(Iscde), 554-557.

52. Supriana, I., Agustin, R. D., Bakar, M. A., and Zin, N. A. M. (2017). Serious Games for Effective Learning.

53. UNESCO. (2003). Technology Education Guide. 153.

54. Venkatesh, V. (2000). Determinants of Perceived Ease of Use: Integrating Control , Intrinsic Motivation , and Emotion into the Technology Acceptance Model. 1997, 342-365.

55. Venkatesh, V., Thong, J. Y. L., \& Xu, X. (2012). Consumer Acceptance and Use of Information Technology: Extending the Unified Theory of Acceptance and Use of Technology. MIS Q, 36(1).

56. Venkatesh, V., Morris, M. G., Davis, G. B., \& Davis, F. D. (2003) User acceptance of information technology: Toward a unified view. MIS Q, 425-478.

57. Yadegaridehkordi, E., \& Alaa, M. (2017). Mobile Learning for English Language Acquisition: Taxonomy, Challenges , and Recommendations. 5.

58. Zhang, Y. (2016). The Impact of Mobile Learning on ESL Listening Comprehension. (5).

59. Zhonggen, Y. (2019). A Meta-Analysis of Use of Serious Games in Education. International Journal of Computer Games Technology, 2019(3).

\section{AUTHOR PROFILE}

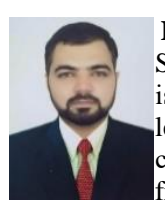

Kashif Ishaq is a Ph.D. scholar in Faculty of Information Science and Technology, Universiti Kebangsaan Malaysia. He is working on his Ph.D. research title "English Language learning serious game design model for primary school children". He received his Masters in Information Technology from Department of Computer Science, University of Management and Technology, Pakistan.

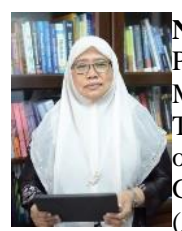

Nor Azan Mat Zin received the Ph.D. in 2005 and working as Professor in Research Centre for Software Technology and Management (SOFTAM), Faculty of Information Science and Technology, Universiti Kebangsaan Malaysia. She is the Head of Games lab, Multimedia Software and Usability Research Group and area of specialization is serious games, HCI (Accessibility), E-learning Technology.

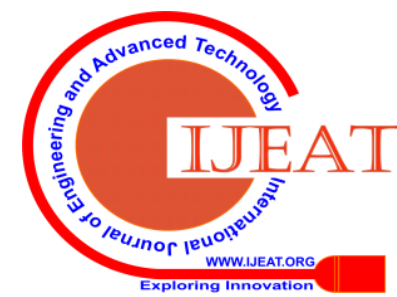




\section{Usefulness of Mobile Assisted Language Learning Application}

Adnan Abid was born in Gujranwala, Pakistan, in 1979. He received the B.S. degree from the National University of Computer and Emerging Science, Pakistan, in 2001, the M.S. degree in information technology from the National University of Science and Technology, Pakistan, in 2007, and the Ph.D. degree in computer science from Politecnico Di Milano, Italy, in 2012. He is currently an Associate Professor with the Department of Computer Science, University of Management and Technology, Pakistan. His research interests include computer science education, information retrieval, and data management. He is a member of the IEEE Computer Society.

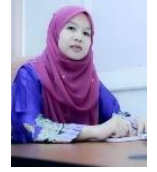

Fadhilah Rosdi received the Ph.D. from University of Malaya and working as Senior Lecturer in Research Centre for Software Technology and Management (SOFTAM), Faculty of Information Science and Technology, Universiti Kebangsaan Malaysia. Her area of specialization is Speech Processing Knowledge Based System.

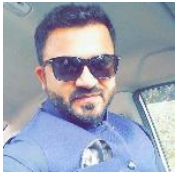

Qasim Ali is received his Masters in Information Technology from Department of Computer Science, University of Management and Technology, Pakistan. He is working as mobile game developer and his area of specialization is serious games and usability. 